\title{
Discernment or Direction: Dancing with the Spirit as we step out in Mission The Fernley-Hartley Lecture, 2019
}

Joanne Cox-Darling

Wolverhampton, United Kingdom

Abstract: This article draws from the developments in pneumatology, especially in respect to how the Spirit calls God's people into mission and missional endeavour, in order to offer a critical insight into how the Fresh Expressions movement continues to equip the church to live faithfully. To do this, the article utilises research from ecumenical partners in mission in the UK, before arguing that Fresh Expressions (as an organisation as well as a set of principles and practices), has inherited much from the work of the Holy Spirit, but had not gone far enough to draw further conclusions or to self-resource itself from a strong pneumato-missional perspective.

Keywords: Pneumatology • missiology $\bullet$ Fresh-expression $\bullet$ Methodist $\bullet$ Spirit

A Form Of This Essay Was First Delivered As A Fernley-Hartley Lecture In 2019

First, why is the topic of the Holy Spirit so pertinent to mission studies and missional praxis today? The now-almost twenty-year old Fresh Expressions movement (FX) is one response the mainstream (UK) Methodist and Anglican Churches have made to an international rediscovery of the power of the Holy Spirit as both a catalyst for mission, and as an academic discipline. The growth of FX is part of that confluence, and as such we need to locate what is happening on an academic global and historic map.

Secondly, having looked at the macro picture, it is necessary to drill down into the micro, and set the context for our ongoing conversation in the researched world of FX-highlighting firstly the Methodist interrogation of statistics from 2016/17 (being some of the most detailed quantitative data we have available to us); and offering a comparison with data taken from the recently published research into Leicester diocese.

Thirdly, and most substantively, three things that Fresh Expressions has facilitated when we are considering the dance of the Holy Spirit are considered, if we are going to continue to partner with the Holy Spirit in God's mission. This section argues for deeper understanding and practice of mystical spirituality, honesty about the current limitations on missional practice (despite the possibilities within the models), and a final challenge to push Fresh Expressions further in terms of liberation and systemic change for the whole world.

\section{An Introduction to Contemporary Pneumatology}

Renowned international Professor of Pneumatology, Kirsteen Kim, has suggested that 'the Holy Spirit is the Cinderella of [academic] theology.' It has been an oftentimes maligned and ignored member of the Trinity, and 
the Spirit is often seen in a supporting act to God's creativity and Jesus' death-defying resurrection; rather than a leading role in the whole of salvation history.

However, now, it seems, is time for the Cinderella of Theology to don her glass slippers, and to join the party. There are a few significant protagonists who have helped to shape contemporary thinking over the last half a century, as missiology and incarnational Christology have taken precedence in ecclesiastical and ecumenical policy making and praxis.

David Bosch. As with much contemporary missiology, it probably all started with David Bosch and his seminal work Transforming Mission. In it, Bosch traces the history of Christian mission. Bosch offers an in-depth narrative of Christian missionary expansion, but also helpfully begins to distinguish mission from evangelism. Thus, theological dynamics of mission, and how it has changed over the course of Christian history is somewhat separated from the accompanying systematics and apologetics of doctrine and proclamation. Mission is the defining characteristic of God. Evangelism is how God's people choose to talk about, and describe, salvation.

Most significantly for the purposes of a study of pneumatology, Bosch's contribution comes with his conclusion that "the church doesn't have a mission. God, Father, Son, and Spirit, has a mission. And God has a church." (sic)

'mission is primarily and ultimately the work of the triune God, creator, redeemer, and sanctifier, for the sake of the world, a ministry in which the church is privilege to participate in. Mission has its origin in the heart of God."1

Mission is both a function of, and an identity within, the triune God. Mission isn't something that God does to the world. It is both part of God, and part of the response of God's creation. Mission is not, and should not be, done unto people-which is why a strong theology of the Holy Spirit is needed, but which arguably Bosch neglects to highlight. The result of Missio Dei praxis under Bosch is that following God into mission is still 'an activity of the Church'-and that mission is still a formal strategy of a church organisation, rather than a spiritual discipline. ${ }^{2}$

Recently, on the floor of the General Synod of the Church of England-nearly two decades into the work of Fresh Expressions-a representative stood up and asked how it was possible to know the difference between a God idea or a good idea. Getting the relationship between mission and the Holy Spirit would be a helpful place to start. When mission, even following Missio Dei, is a strategy and an item on the agenda, it comes with the consequence of analysing success based on capitalist and consumerist objectives, rather than social values.

Philip Jenkins. Jenkins' contribution to this debate reminds us that talking about the Holy Spirit and mission is not merely the task of the West-and that for all that is written in this paper from a UK context, the Global South has got more to offer. Jenkins traces the development and formation of Christian identity in the Global South - both showing the impact of traditional models of missionary activity to indigenous populations, as well as recognising that some of the fastest-growing congregations of recent times have flourished independently of the crusades and church mission teams. Jenkins potentially veers too closely to the mission as 'doing and being done to' mode, rather than a deeper engagement with what the character of a missional, Spirit-led, God might be. However, his observations critically remind those in power in the West do not have the only story to tell-and that a Fresh Expression borne out of the Church Growth agenda of the late 90s risks failing to fundamentally understand the lessons of church growth-amongst the poor, the illiterate, the war-torn, the desperate, and the forgotten. Jenkins offers a helpful reminder that pneumatology includes the mystical and the supernatural; and that no formal strategy can ever leave enough space to let the Spirit have agency over another:

'these newer churches preach deep personal faith and communal orthodoxy, mysticism, and puritanism, all founded on clear scriptural authority. They preach messages that, to the westerner, appear simplistically charismatic, visionary, and apocalyptic. In this thought-world, prophecy is an everyday reality, while faith healing, exorcism, and dream-visions are all fundamental parts of religious sensibility.' ${ }^{3}$

Phyllis Trible marks the shifting sands of pneumatology, suggesting that the advent of postmodernity brought with it a renewed energy for the spiritual:

'Emerging, then, was the Age of the Spirit...a time when humankind would relate primarily to the third member of the Trinity. This would be a moment marked by a decreased importance in ecclesial structures, sacraments, creeds, and clergy, when all people would begin to relate more directly as 'friends' with the Divine. ${ }^{44}$ 
Utilising the sociological work of Grace Davie and others, feminist theologian Trible traced the early shifts of the emerging church movement, and recognised them as more than good ideas of creative and disinterested leaders and their groupies, but instead began to talk about a new reformation. This oncoming storm of Spirit-led, creative, power and hierarchy-toppling energy is fuelled by what Trible noted was 'the age of the Spirit'. An age of innovation and equality, which would see Christendom models of powers and dominions crumble, but that the Holy Spirit would bring wildness and courage to God's people.

In this mission-centred world, we often talk about mission happening on the margins of the church and on the margins of society. It should be no surprise, therefore, that in order to garner a deeper understanding of, and respect for, the missional Spirit at the heart of this seismic shift in understanding, we should be looking to the margins too. Jenkins and Trible do this time and time again, constantly reminding us the mission is an outward movement within the realm of the other. If we are not influenced by, and working in, the margins, then we are missing a fundamental understanding of the nature of the wild and wily Holy Spirit.

Kirsteen Kim, straddling her English-Korean cultural heritage, embodies this need for cultural and geographic diversity in our discussions about the Holy Spirit and mission, and she offers one of the earliest and most detailed narratives about the history of pneumatology as a distinctive theological discipline. Her work is key to understanding much of what has been written and built upon, and yet she herself is often as Cinderella as the subject she is so passionate about.

Kim critiques Bosch, suggesting that he did not go far enough in his missiology. Kim suggests that if the heart of God's character is mission, the Holy Spirit is not about more church activity, but about systemic, cultural, socio-political change within the very fabric of the created order. Kim, utilising the earlier work of Walter Wink and others, draws attention to the structural endeavour of missional spirituality. For Kim, following the missional Spirit is not about programmes and events, but about God's activity bringing forth the kingdom of God.

Kim was also an important contributor to the 2012 World Council of Churches Statement on mission and evangelism. This key document, 'Together Toward Life', is both a politically charged and theologically rich document, agreed to by all members of the WCC. It pulls together the strands of Global South praxis, liberation spirituality, and Western missionary practices-and demands of the whole Church a definitive definition and distinction between mission and evangelism but does so unapologetically Spirit-led and Spirit-focused.

If the missional Spirit is at work throughout the world and within God's created order (this document is perhaps one example of that) as generous orthodoxy in action, recognises that the driver of mission is the Spirit, not hard work and winning arguments.

Amos Yong, a colleague of Kim at Fuller, pushes her work of the Spirit still further. Rather than relying on the churches' inheritance as a theology of missiona set of practices that a church would perform because it is the outworking of their sense of calling and identity as a commissioned community-Yong instead argues that all mission is pneumatological. As a consequence, the Trinity is driven by the Holy Spirit in mission, and that all God-given activity and human participation is in the power of the Spirit. His contestation remains that the vital (and often missed component) for understanding God's missional character and endeavour needs to be through the lens of the character of the Holy Spirit rather than through the function or action of the Spirit.

Once again, Yong is trying to dust off the ball gown of the Spirit and invite the church to relearn the steps of the Divine Dance. What if it is the Spirit that takes the lead in the Divine Dance, and not the creator or the saviour parts of the Trinity? When this happens, the Spirit blows where it wills-but it means that God is ever present, ever powerful, ever seeking, and ever loving-in ways that are wild and uncontainable. For Yong, this missional pneumatology is about reconciliation and peacefulness, the ultimate shalom of the Kingdom of God. The Spirit is ever present and active even in the places where the Church is not (and as an aside, how different tough conversations about church closures would be, if we truly believed this too!)

For Yong, this missional spirit in action is about the building of relationship, the repair of creation, and the full participation of all people from all places in the kingdom of God-rich in diversity and complexity.

All of these voices suggest that a day like today, focussed on the Holy Spirit, is more than just nostalgia for the good old days of charismatic worship experience.

These writers and thinkers are behind the scenes when we begin to talk about discernment and direction in the midst of Fresh Expressions. Over the last quarter of a century, academic theory, as well as local praxis, has moved from a rediscovery of understanding that mission activity is God's, and that mission is God's character first and foremost, to a greater understanding of marginal and liberation voices shaping our understanding of the work and character of the Holy Spirit. Pneumatology infects and affects everything around us. Missional spirituality is as much about contemplation and reconciliation as it is about invitation and argument. 
But what does this look like in practice, through the lens of Fresh Expressions? The following is a summary of some of the most recent research into Fresh Expressions in the Methodist Church in Britain, triangulated with a detailed study of Fresh Expressions in Leicester Diocese.

\section{METHODISM $^{5}$}

A 15-year journey, nationally, provides the following statistics in the most recent research, published based on the returns and interviews following the 2016 statistical return:

2016/17 - 1000 Fresh expressions reaching 4,500 churches in 31\% circuits, with a weekly attendance of 14,500 people, $38 \%$ of whom are under the age of 16 .

$19 \%$ of participants have had some formal recognition of baptism or membership

$0.5 \%$ have taken the step to be formally recognised churches in their own right - meaning that the majority are still projects or activities of the church, underrepresented on church council, and often at the budgetary whim of a parent congregation.

Research suggests $7 \%$ of people in a worshipping Methodist context are involved in Methodism

$59 \%$ leaders are lay, $64 \%$ are women

$46 \%$ of Methodist fresh expressions leaders were voluntary/unpaid, $16 \%$ were locally paid and $38 \%$ were stipendiary (although since we do not have a formal status for pioneers, we can assume that stipendiary leaders are also in wider circuit or district appointments)

In contrast...

LEICESTER ${ }^{6}$

The diocese began investing in FxC in 2011 (Budget of $£ 800000+$ ), and now, in 2019 there are 4,378 people in the 99 worshipping communities surveyed.

Over 1 in $4(26 \%)$ of people attending worship in the diocese now do so at a fresh expression of Church. FxC account for $19 \%$ of the overall diocesan 'worshipping community'

Predicted that $75 \%$ will have been baptised or confirmed from within the FX

$66 \%$ of all core leaders were women. $85 \%$ of all core leaders were unpaid. $74 \%$ were unlicensed 'lay-lay' leaders.

When Church Army's Research Unit last reported in 2017, we noted that just over $30 \%$ of fxC begun in the diocese of Leicester had come to an end. One of the benefits of conducting this research over an extended period is that we can now report that since $2015 \mathrm{fxC}$ in the diocese appear to have become more resilient.

Crucially, these tell us that:

- FX has had an impact, and the praxis of (even if not the understanding of) Missio Dei is in the bloodstream

- FXs are led largely by unpaid, untrained volunteers - the majority of whom are women

- mixed evidence about the commitment of those involved - in terms of baptisms, confirmations, and the formal identification of churches over projects—but without the impact markers for softer forms of measurement.

The missiological spirit is at work, and the ecclesiological tide is turning, albeit being such a force of money, power, and politics that any innovation has to fight hard to be anything other than an expensive extravagance in times of dwindling budgets and stretched clergy.

\section{Putting it into practice}

This final section draws the following three conclusions:

First: Missio Dei versus Mysticism

Secondly: Has the church left the building

Thirdly: Love Wins? 
Each recognises something that Fresh Expressions has contributed to the field of missional spirituality. This is then used as a catalyst to challenge the institution, and practitioners - to think further, deeper, higher, and more broadly about the implications of the mission of the Holy Spirit, and mission with the Holy Spirit.

\section{Missio Dei Versus Mysticism}

Perhaps more than any other invention, programme, or focus of the last quarter century, Fresh Expressions has done more to raise the understanding and practice of Missio Dei than anything else. Fresh Expressions has given a language to leaders who wanted to engage with people outside of the church building, and who have noticed those pockets of peace where something beautiful begins to blossom. Whether it is a child's soft play centre or a place for people to learn how to fix their school uniforms, Fresh Expressions has given a language for, and permission to, see this as ministry and calling, rather than an unnecessary luxury.

Even outside formally recognisable fresh expressions of church, congregations are beginning to rely on the missional nature of God-especially, and somewhat ironically, often in the midst of change and closure. Fresh Expressions was designed to bring life and partnership and growth, but in the midst of a dying institution, it remains significant that many of these conversations over congregational failure are now more mission-centred and God-focused.

There remain significant limitations to the development of a spirituality for mission for leaders within Fresh Expressions. Leaders are failed (and failing) by not resourcing them well enough for the long haul. Institutions are not listening hard enough to practitioners who, years into their Fresh Expressions journey, are discovering a mystical Christian spirituality, often in relationship with non-churched congregants.

A former employee of Fresh Expressions has reflected:

One area that really interests me is spiritual accompaniment. I'm aware of increasing numbers of pioneers seeking training in and offering spiritual accompaniment and/or life coaching to people beyond the church. I do think this is potentially a rich area for growth in terms of sharing Christian contemplative and mystical theology/practice with people who are not church goers but who are open to it or indeed feel desperate thirst for it. I meet those people loads. I think to really begin to grasp contemplation or mysticism, the spiritual accompaniment training offered around the country may be better placed, or engaging with traditional monastic communities.

The other thing l'd say is that serious engagement with contemplation and mysticism usually leads to a lack of defensiveness- the engagement of curiosity in place of fear, which I think the church really needs currently. I think we need to stop trying to make it work and start expecting God to speak to us through people who do not call themselves Christian. Why are we so afraid of people who are different from us? When did we forget that the Holy Spirit was always working in people before we showed up? ${ }^{7}$

If we are to take seriously the conversation about a pneumatology of mission, then assessment criteria and reflection questions for observations need to be spirit-focussed too. The statistics are helpful as they tell part of the story-but they do not talk about the spiritual health and well-being of community or leader. Attendance alone does not speak of the quality of discipleship or the depth of spirituality. They do not reflect on whether the Missio Dei is in fact the driver for mission, or if the more ubiquitous 'theology of desperation' is more prevalent.

It is God's mission, but churches are still behaving as if it all depends upon salvific charismatic leaders who give all of themselves to the ministry. For this reason, denominations are now tempted to invest in numerically viable transpositions of large middle-class churches, which consequently means that policymakers still contain the work of the Spirit within 'what works' and 'what is numerically growing' rather than the wild and more edgy extremes of pioneering ministry which, especially on the margins, are unlikely to be repeatable.

In turn, there is a huge juxtaposition, a culture clash, between Fresh Expressions of church being led by unpaid lay women and the ongoing discovery and discussion about the significance of monastic, mystic, and Celtic spirituality and spiritual practices for pioneers.

Elaine Heath says 'the church is in trouble in the post-Christendom west, the kind of trouble that requires leadership from those who are holy. The great Christian mystics are our exemplars of holiness. ${ }^{8}$ Unpaid, hardworking, untrained, 
faithful volunteers have been and will be the mainstay of the church. However, they are often able to describe themselves or their spirituality in terms of mystical, monastic, or Celtic spirituality. Most of our clergy are not like that, either.

It is fascinating, therefore, that at least half of the people called into the Venture FX pioneering world would, or do now, describe themselves as having a mystical spirituality, which is grounded in an understanding an experience of seeing the Spirit at work in the world all around them. This is one example amongst many of the lessons the church seems unwilling to hear in the wildness of the Spirit at work.

Historically, one of the key influences upon Fresh Expressions was the work of the emerging church movement. From Sheffield's nine o'clock service packed full of music and creativity and ritual and liturgy to the prophetically contemplative alternative service at Grace in Ealing, the emerging church leaders more than any other of the FX pioneers, recognised the importance of creation-laden spirituality, for the community as well as the leaders.

Given than many of these early (male) leaders-Doug Gay, Brian Draper, Jonny Baker, lan Mobsby, Pete Rollins ... even Graham Horsley-had themselves travelled and travailed through the rise of the charismatic movement of the eighties and early nineties, it is no surprise that for them, a rich and mellow creation-focussed spirituality was at the heart of their own spirituality and leadership. Caricatured as post-charismatic, and dismissed in the USA as 'they like spirituality but don't really know Jesus', what Fresh Expressions, and mission leaders and writers have not quite taken seriously enough is the impact of being steeped in charismatic spirituality and spiritual practices prior to throwing it off, or refocusing it within a post-charismatic, post-Christendom, framework. The initial leaders and influencers in Fresh Expressions, pioneering and emerging church already had the language, experience, and currency of the Holy Spirit as agent in the world. This is missing in many of our Fresh Expressions today and is a weakness of the developments of Fresh Expressions as a global movement, as this expectation on the Spirit's participation is difficult to teach in a training session.

What is currently perpetuated are well meaning leaders doing their best, but without the spiritual wells of energy and resourcing to support and sustain them (let alone their communities) for the long haul.

We have not heard the distant whisper from one pioneer:

"I'm tentatively feeling my way into spirituality that is a long way from the safe shores of doctrine and liturgy I cast off from months, maybe years ago, shores that I used to return to frequently but my visits to gentle harbours became fewer and fewer until I found myself in the Oceans of deep unknown"

Or from the broken soul of another former pioneer:

'I am a mystic. I live by the sea now. I used to live surrounded by the mountains. I see God in rhythms and nature and the stars ... but the straw that broke the back of my faith was the day someone said that my spirituality was 'airy fairy.' That hurt me, because my spirituality is who I am. In that moment everything about me, everything I offered, and everything I knew of God was reduced to pointlessness. I haven't been back to church since.'

If Yong, Rohr, Kim, Bosch, Heath, Trible, and countless others are right, and that the Holy Spirit is the drive, dance partner, catalyst, or presence in mission, then we need leaders who know the Spirit as 'ancient, real, raw, dirty and wild.', who aren't dismissed as naive, but who are in touch with the rhythms and depths of a spiritual life that the rest of us only dream of between church councils and management meetings. Leaders who lead out of their brokenness, and who walk with those who are hurting; who embody a prophetic peacefulness in a chaotic and terrifying world, and who experience the Spirit dancing in the fabric of the everyday, at apple tree blessing ceremonies and rogation rituals; to conversations in coffee shops and shared learning in workshops.

Denominations are recruiting and training people to be social entrepreneurs (as the CMS and Cliff College programmes demonstrate), and expecting them to transpose the language of Missio Dei onto that experience. What we need is more people listening with one ear to the context and the other ear to the heartbeat of the Spirit, calling a deeper world and experience into being.

The mission-shaped ministry course needs to teach spirituality, rather than creative worship moments to pep up a session.

Leaders need to be selected on the basis of spiritual discernment, rather than by a job description.

Our qualitative assessments need to ask questions about spiritual health-to all of our congregations.

And we need to release our leaders, lay and ordained, to find spiritual practices and retreat spaces which take them outside, into the fresh air, that they might breathe of the Spirit afresh. 
As Yong says, 'The Christian mission unfolds as much through the people of God BEING the Church as it does through followers of Jesus DOING missionary works.'

Such a vision is threatening to the institutions and powers of today. It is wild and reckless and uncontainable and uncontrollable, and peaceful and reconciling and about justice, and instinct; it's poetic and rhythmical, and full of patterns and opportunity, and relationality, and seasonality, and mindfulness; and it's indescribable, and powerful, and storied, and visceral, and tantalising. Now that is the sort of missional spirit that is growling and prowling at the margins. And it is not as tame as our institutions-denominations or Fresh Expressions—would like to imagine.

\section{Has the Church Left the Building?}

Fresh Expressions has helped to encourage the church to leave the bricks and mortar, and to engage with the local community. In some places, this has looked a lot like community organising principles. In other places, it has been an opportunity to reflect on how a church building once served a particular community, but now the community has moved away. It has given an invitation to notice footfall and flow, and to notice the demographic changes within a parish, circuit or locality.

However, when the statistics suggest that $90 \%$ of Methodist Fresh Expressions still meet in a church-and Sunday congregations still expect the Messy Church family to turn up on a Sunday morning in order to belong to the church family - the centripetal concept of mission within Fresh Expressions still seems to be ecclesiologically dominant.

The missional spirit of Fresh Expressions would resist this, and rightly so: mission is about joining God outside of church and seeing what happens when people walk together to an unknown destination. The reality, even twenty years on, contradicts this.

One consequence of this is that Fresh Expressions of church are not as courageous, brave, or wild as they could be (or that the Spirit is birthing). Communities understand the social part of the holiness movement, on their own turf and in the comfort of their own power and hospitality, but they still remain host and invite the world to be their guest.

In order to revisit Wesley's insistence on social holiness, pneumatologically powered, it can be argued that a new phrase is needed: Systemic holiness. For Wesley, social holiness was a communal response towards God, and a way of seeing God's kingdom come. Holiness was nothing less than a new creation and a new world order.

In order to counteract the misappropriation of the social, to challenge our propensity towards individualism, and to set social holiness in a global and globalised context, Systemic holiness reminds us that God is within the fabric of the whole of creation and that the salvific act of the gospel is renewing and transforming all the principalities and powers within it.

Now, more than ever, the church has a role to play in changing the world systems of money, sex, and power.

Systemic holiness recognises that the missional Spirit is redeeming and reconciling the whole world. The church is one vehicle by which God's mission is enacted, but the church is the group of people, not bricks and mortar.

For Fresh Eexpressions, the challenge is this: to what extent are they trying to perpetuate a social club-and to what extent is joining in on God's mission about prophetic actions of radical justice and civil disobedience?

Where are the Fresh Expressions of church which are pioneering carbon-neutral worship, or building on the forest church model of Celtic spirituality?

Where are the Fresh Expressions of church which are craftivist, where senior leaders do not dismiss the work of a Fresh Expression as 'not going to change the world through a sewing machine,' but instead craft policies that see the church become carbon-neutral ahead of the pervading society?

What might a franchise model of a Fresh Expression of church look like if it is to work to change the mental health of our young people across the UK, rather than keep families in church for as long as possible?

As Heath notes,

'the gospel witness has to be lived out, not just proclaimed....the holy life is one that is fully engaged in this world in the name and power of Jesus Christ. As the lives of so many great saints and mystics demonstrate, the more one advances in the way of holiness, the more one must wrestle with powers and principalities. ${ }^{10}$

Systemic holiness is about joining with the missional spirit to change the principalities and powers which perpetuate decline, death, disorder, and despair. 
As Methodists, with a strong history of education, health and well-being, anti-poverty-and even teetotal-ministries, where are our prophets and our practices which reinvigorate a passion for systemic change at a time of deep unrest and inequality?

'with today's mushrooming environmental crisis, the church has unprecedented responsibility to practice eco-evangelism, an essential element of a contemplative stance. The church is charged with speaking, being, and doing good news to the earth and all its creatures.'11

We reduce mystic spirituality to airy fairy nonsense.

We talk of Fresh Expressions as playing at church.

And still the world burns.

But so does the Spirit.

And the Spirit of God prowls and invites us to change the narrative.

To join in the task of mission and evangelism, to redeem the whole of creation and to bring to birth a new world order, shaped into the kingdom of God.

If only the Church dares to really leave the building and follow where the Spirit is leading.

\section{Love Wins?}

One rather unexpected move of the Spirit within the institutions most impacted by the language and method of Fresh Expressions has been the adoption and adaptation of some of the language: not least of all the language of 'mixed economy.'

It has cropped up in all sorts of places to describe a whole manner of things.

Initially used to describe the spiritual space for experimentation and risk taking within a denominational or church setting, 'mixed economy' has been used to describe vocations, mission, and most recently of all, to describe proposals being brought before the Methodist people on the subject of human sexuality and relationships.

Fresh Expressions has, therefore, further enabled the church to recognise its breadth, and have also taken to heart the Wesleyan tradition of the open table - that sense where the community of faith has space for anyone around it. The language and practice of a mixed economy has enabled debate over doctrine to come second to building and crafting relationships - in the community, within denominations, and more widely.

Fresh Expressions has given language to, permission for, and examples of how to enable churches and communities to disagree well, and how to seek the kingdom of God together. At its richest and with the most potential, Fresh Expressions teaches the contemporary church how to live peaceably-in partnership with the shalom spirit of liberation theology - the peace that surpasses all understanding, which welcomes and nurtures those on the margins, the excluded, and the poor, and gives them a place of prestige and welcome and freedom in the kingdom of God. That spirit of peace which isn't anything to do with being nice or courteous, but is instead about deep-seated justice and social (systemic) change.

However, in the midst of mutual flourishing (to use another loaded, but less popular turn of phrase), Fresh Expressions has not always been this brave and courageous in its own practice and development. For example, Fresh Expressions of church extends welcome through offering blessing and acts of kindness and by building relationships, but very few actually embody the costliness of inclusion, or even wrestle with the challenges doctrine makes when inclusion meets certain interpretations of Scripture.

Bosch says that, 'God is a fountain of sending love. This is the deepest source of mission. It is impossible to penetrate still there is mission because God loves people'. ${ }^{12}$

Heath goes even further:

'the hermeneutic of love is grounded in the belief that Jesus really does live in the people around us, that Jesus thirsts in our actual neighbourhood. Jesus is bound with eternal love to every person I encounter. This is the starting point. When I see people that way, everything changes. How I evangelise changes. My ecclesiology changes. Now I see people already being called by the Holy Spirit, already being loved and known by Jesus before I ever met them.'13 
And yet, within all the research and data collected on Fresh Expressions, and even in many of the stories told and shared about the impact of Fresh Expressions, it is very rare that this transformative, world-changing, barrierbreaking, inclusive, open table, broken bread, radical hospitality sort of love is communicated or monitored. The Christian church has no qualitative way to measure whether they are actually a loving community, or to measure the reach of that loving community.

It is easy to forget that at the heart of the majority of Fresh Expressions are unpaid, overworked, lay women tirelessly setting out the chairs and putting on the kettle, who themselves are loved by the creator of the world. Mixed economy crops up when discussing disagreement, but when we talk about an economy, we slip into an unconscious consumer mindset of Protestant work ethic and wrongly start to believe that all that is needed is more and more and more hard work.

It is easy to forget that in the mixed economy, there is space for leaders too to be loved, to receive the peace of the Holy Spirit, and to be God's best.

As Rohr reminds us:

'The love in you - which is the Spirit in you - always somehow says yes. Love is not something you do; love is someone you are. It is your True Self. Love is where you came from and love is where you're going. It's not something you can buy. It's not something you can attain. It is the presence of God within you, called the Holy Spirit ... uncreated grace.' ${ }^{14}$

The mixed economy needs a recession, and instead investment needs to be in uncreated grace.

Quantitative social measures for love and inclusion in congregations as well as in theology are required for all parts of our denominations and institutions.

There is a gap in the market for Fresh Expressions which demonstrates a world-changing power of the spirit of God which rains down justice and shalom, liberating people and communities and creation to their true self.

\section{Conclusion}

There is much to celebrate when we talk of the Holy Spirit in Fresh Expressions-from the deep academic thinking which has influenced us to this place, to the mystics and Celts in whose feet people dare to tread; the inheritance of language which reveals more of God to the world in Missio Dei and more of God to the church in a mixed economy. As ever, the Spirit is wild and uncontainable and free-and these few minutes spent unearthing her secrets is only a small part of her wild, dirty, raw, movement within our world-and within the kingdom of God. The missional Spirit draws back to an ancient future pattern of faith which needs to be experienced and become part of us as followers of the Holy Spirit in mission. The Gospel is good news for the whole of creation, and so this paper calls for a systemic holiness to inspire us to more acts of peaceful civil disobedience and prophetic action as we seek to live into God's vision for the world; and in all things, the spirit of love sets us free to be the people we are created to be; and that means being loved and loving in return. It's generous, radical, gracious, and overwhelming, but it means that the Spirit of God ministers to us in mission, as much as she calls us out in mission.

\section{Notes}

[1] David Bosch, Transforming Mission (Maryknoll, NY: Orbis, 1991), 392.

[2] Kirsteen Kim, Joining In With the Spirit: Connecting Local Church and World Mission: Connecting World Church and Local Mission (London: SCM, 2012), 174.

[3] Philip Jenkins, The Next Christendom: The Coming of Global Christianity (Oxford: Oxford University Press, 2002), 10.

[4] Phyllis A. Tickle and Jon M. Sweeney, The Age of the Spirit: How the Ghost of an Ancient Controversy Is Shaping the Church (Grand Rapids, MI: Baker Books, 2014), 112.

[5] Methodist Church, "Methodism's Hidden Harvest: The Story of the First Fifteen Years of Methodist Involvement in Fresh Expressions," 2019, https://www.methodist.org.uk/media/14851/3307-fx-research-report-methodism-shidden-harvest.pdf. 
[6] Diocese of Leicester, "God at Work: Learning about Fresh Expressions of Chuurch and Other Pioneering Missional Activities within the Diocese of Leicester," accessed September 30, 2021, https://www.leicester. anglican.org/content/pages/documents/1570031088.pdf.

[7] This, and other quotations, are from the author's research and are anonymous at the request of participants.

[8] Elaine Heath, The Mystic Way of Evangelism: A Contemplative Vision for Christian Outreach, 2nd ed. (Grand Rapids, MI: Baker Academic, 2017), 12.

[9] Amos Yong, The Missiological Spirit: Christian Mission Theology in the Third Millennium Global Contex, (Eugene, OR: Cascade Books, 2014), 224.

[10] Heath, Mystic Way of Evangelism, 59.

[11] Heath, 171.

[12] Bosch, Transforming Mission, 392.

[13] Heath, Mystic Way of Evangelism, 125.

[14] Rohr, Richard, The Divine Dance: The Trinity and your transformation,(London, SPCK, 2016), 193. 